Revista da Associação Nacional dos

Programas de Pós-Graduação em Comunicação

e compós

www.compos.org.br

\title{
Do caráter negociável da significação à busca do código perfeito ${ }^{1}$
}

\author{
Humberto Ivan Keske ${ }^{2}$ \\ Doutor em Comunicação Social \\ Programa de Pós-Graduação - PUCRS \\ Professor de Graduação e Pós-Graduação do \\ Centro Universitário Feevale - Novo Hamburgo - RS
}

\begin{abstract}
Resumo: Resgatando algumas questões trabalhadas no modelo informativo de Shannon e Weaver (1948), acrescidas das ampliações de Umberto Eco e Paolo Fabbri nos dois modelos comunicacionais seguintes, o modelo semiótico-informativo (1978) e o modelo semiótico-textual (1979), o presente artigo visa problematizar a relação estabelecida entre a noção de código e as circunstâncias de comunicação, entendidas aqui como aqueles elementos participantes de uma dada situação concreta que auxiliam na compreensão entre o remetente e o destinatário, interferindo diretamente no processo de (re) significação das mensagens. Longe de produzir uma transmissão da informação de sentido unívoco, a heterogeneidade de fatores envolvidos no processo comunicacional traz à tona complexos jogos interpretativos que competem na atualização de uma determinada significação. A pesquisa apresenta, como objetivo principal, fazer uma revisão bibliográfica das principais obras no tocante à temática proposta, contribuindo para a ampliação do campo da Comunicação Social na relação estabelecida com suas diferentes linguagens.
\end{abstract}

Palavras-chaves: Teorias da Comunicação; significação; sentido; código; circunstância de comunicação.

\begin{abstract}
Rescuing some issues worked in the information model of Shannon and Weaver (1948), plus the extensions of Umberto Eco and Paolo Fabbri in the two models following communication, the model semiotic-information (1978) and model semiotic-textual (1979), this article aims to discuss the relationship between the concept of code and the circumstances of communication, understood here as those elements participants of a given concrete situation which assist in understanding between sender and recipient, directly interfering in the process of (re) signification of the messages. Far from producing a transmission of information from unequivocal meaning, the heterogeneity of factors involved in the communication process brings afloat complex interpretative games that compete in the update of a particular signification. The survey shows, as its main objective, to make a bibliographic review of the major works regarding the subject proposal, contributing to the expansion of the field of media in the relationship established with its various languages.
\end{abstract}

Keywords: Theories of Communication; signification; meaning; code; circumstance of communication.

\footnotetext{
${ }^{1}$ Trabalho apresentado ao Núcleo de Pesquisa 01 - Teorias da Comunicação, do VI Encontro dos Núcleos de Pesquisa da Intercom - XXIX - Congresso Brasileiro de Ciências da Comunicação - 06 à 09 de setembro de 2006 - Brasília - DF.

${ }^{2}$ Doutor pelo Programa de Pós-Graduação em Comunicação Social - FAMECOS - PUCRS e Professor de Graduação e Pós-Graduação do Centro Universitário FEEVALE. - Novo Hamburgo - RS. E-mail: humberto@feevale.br
} 


\section{Introdução: em busca de outras codificações}

A teoria matemática da comunicação, enquanto processo comunicacional, consistia em reproduzir, em um determinado ponto, de maneira exata ou aproximativa, uma mensagem selecionada em outro ponto. Na perspectiva do modelo informativo, como ficou conhecido, a informação era tratada apenas como símbolo calculável, ou seja, devia existir uma fonte de emissão da informação, a partir da qual era emitido um sinal, através de um aparelho transmissor; esse sinal viajava por um canal, ao longo do qual poderia ser perturbado por um ruído. Quando saía do canal, o sinal era captado por um receptor que o convertia em mensagem que, como tal, seria compreendida pelo destinatário.

Shannon e Weaver (1948), idealizadores desse sistema, procuraram estabelecer o modo mais econômico e rápido de codificar uma mensagem, sem que a presença do ruído tornasse problemática a transmissão. O que importava para os autores era pôr em código uma determinada mensagem, e não estudar e compreender esse código. O que seu estudo privilegiava não era o significado da mensagem, trocada entre emissor e receptor, que se tornava irrelevante, mas sim, a quantidade de informação a ser transmitida. É justamente na apropriação do código por parte dos falantes que Umberto Eco, a partir de 1978, ampliará o modelo comunicacional, acrescentando-lhe a denominação de semiótico-informativo, e contrariando a máxima de que, para que o destinatário pudesse compreender corretamente o sinal, era necessário que, no momento da transmissão ou no momento da recepção, se fizesse referência a um mesmo código. Deste modo,

para melhor compreendermos como acontece esse fenômeno, reconstruamos o esquema comunicacional que nos serviu de ponto de partida, levando em conta o fato de que agora não mais nos interessa distinguir entre fonte e transmissor (um único ser humano), nem estabelecer como é transmitido o sinal inicial e ao longo de que tipo de canal (problema que diz respeito à engenharia das comunicações), mas interessa-nos, isto sim, estabelecer o que acontece. (ECO, 2001: 42).

O modelo semiótico-informativo traz à tona o problema dos processos de significação inseridos no modelo comunicativo da teoria da informação. O modelo 
informativo, de inspiração lógico-matemática, centrava a atenção apenas na eficiência do processo, e não na dinâmica das relações entre o emissor, o receptor e o código. Com o surgimento dos Meios de Comunicação de Massa em larga escala, e a difusão cada vez maior de informações, a atenção da pesquisa passou a se interessar pela capacidade difusora desta informação em transmitir os mesmos conteúdos a um grande público. Em decorrência disso, surgiram pesquisas sobre os processos de decodificação e interpretação das mensagens.

A grande diferença do modelo informativo para o modelo semiótico-informativo é que agora a linearidade da transmissão se encontra vinculada aos fatores semânticos introduzidos mediante o conceito de código. "Isto é, passa-se da acepção de comunicação como transferência de informação, para a de transformação de um sistema em outro. O código garante a possibilidade dessa transformação” (WOLF, 1995: 109-110). Esta modificação do olhar sobre os modelos comunicativos deu-se através da influência de outras disciplinas que provocaram a mudança substancial do paradigma comunicativo anterior: agora, o problema em questão era realmente o da significação inserida nos processos de comunicação de massa.

A preocupação de Eco e Fabbri naqueles anos de 1978 era a de que o modelo divulgado pelos primeiros teóricos da informação, através justamente da fórmula simplificada de um emitente, uma mensagem e um destinatário, onde a mensagem é tanto gerada quanto interpretada na base de um código, não fornecesse os subsídios necessários para a compreensão da complexidade do ato comunicacional. Neste sentido, os códigos do destinatário podiam diferenciar-se, totalmente ou em parte, dos códigos do emitente, o que colocava em observação, justamente, que o processo comunicativo não podia ser interpretado unicamente com base na linearidade da transmissão que o modelo procurava dar conta. Deste modo, chegava-se ao esclarecimento de que

o código não é uma entidade simples, porém na maioria das vezes um complexo sistema de sistema de regras; que o código lingüístico não é suficiente para compreender uma mensagem lingüística: [fuma?] [Não] é lingüisticamente decodificável como pergunta e resposta sobre os hábitos do destinatário da pergunta, mas, em determinadas circunstâncias de emissão, a resposta conota-se como 'mal-educada' com base num código 
que não é lingüístico, porém etiquetal - era preciso dizer [não, muito obrigado]. Por conseguinte, para 'decodificar' uma mensagem verbal é preciso ter, além da competência lingüística, uma competência variadamente circunstancial, uma capacidade passível de desencadear pressuposições, de reprimir idiossincrasias, etc., etc. (ECO, 1986: 38).

Portanto, entre uma determinada codificação estabelecida por um emissor e a respectiva decodificação por parte de um receptor, podia haver a necessidade da interpretação de circunstâncias não-codificadas, que requeriam procedimentos extralingüísticos para os quais concorriam diversos sistemas de signos e códigos que se complementavam e se imbricavam reciprocamente. Tais elementos que se localizavam além do quadro proposto pelo modelo comunicacional seria, posteriormente, chamado por Umberto Eco de circunstâncias da comunicação, conforme veremos.

A multiplicidade dos códigos e das circunstâncias faz com que a mesma mensagem possa ser decodificada de diversos pontos de vista e com referência a diversos sistemas de convenções. A denotação de base pode ser entendida como o emitente queria que fosse entendida, mas as conotações mudam simplesmente porque o destinatário segue percursos de leitura diversos dos previstos pelo emitente (ambos os percursos sendo autorizados pela árvore componencial a que ambos se referem) (ECO, 2000: 127).

Eco e Fabbri (1978) propunham uma visão diferente da idéia simplificadora e reducionista do modelo matemático-informativo, que não levava em consideração o contexto comunicacional e as adversas possibilidades de "leitura" que se apresentavam ao destinatário. Segundo Grandi, “a diferença fundamental entre os dois modelos não se deve somente ao fato de que adotaram uma noção de código diferente, na qual se concede um amplo espaço aos fatores semânticos, mas sim as conseqüências que derivam do modo pelo qual se insere o problema do significado” (1995: 67). Entretanto, o próprio conceito de código também se modificava profundamente, uma vez que, na teoria da informação, a noção de código era entendida somente como a correlação entre elementos de sistemas diferentes. Além do mais, a questão da decodificação, entendida como o processo através do qual os elementos de um determinado público constroem um sentido, a partir daquilo que recebem dos Meios de Comunicação de Massa, adquire uma noção completamente 
ampliada em relação ao modelo informativo, onde se analisava, em laboratório, as condições ideais de transmissão das mensagens.

A partir disto, no modelo semiótico-informativo Eco e Fabbri (1978) salientavam que os efeitos, entendidos "como modalidade de decodificação e de interpretação das mensagens” (WOLF, 1995: 109), e as funções sociais dos Meios de Comunicação de Massa não podiam se desvencilhar dos processos de produção de sentido, uma vez que são partes essenciais do processo comunicativo como um todo. Deste modo, “a noção central sobre a qual se articula o novo modelo é a decodificação, entendida como algo profundamente distinto da simples operação complementar da codificação: com efeito, as diferentes maneiras através das quais o público atribui sentido às mensagens recebidas podem ser muito diferentes da forma pela qual os emissores as tenham codificado" (GRANDI, 1995: $67)$.

O que se percebe no esquema do modelo semiótico-informativo, é que entre a mensagem codificada na fonte e a mensagem decodificada por parte do destinatário pode-se intercalar uma grande variedade de elementos que colaboram para a deformidade do processo de significação. Neste sentido, as diferentes competências lingüísticas, enciclopédicas ou comunicativas em geral e o contexto em que se realizou a mensagem, podem qualificar de modo diferente o emissor e o destinatário, causando a distorção prevista pelo modelo. Além do mais, através da diversidade de códigos e de competências distintas entre emissor e receptor, a interpretação da mensagem assume uma complexidade que pode ser preenchida com vários significados, contanto que existam vários códigos que estabeleçam várias regras de correlação entre determinados significantes e determinados significados.

Temos, assim, a emergência de um modelo semiótico-informativo que procura relacionar ao processo comunicativo o fato de que o significado final da mensagem pode derivar para outros sentidos diferentes daqueles inicialmente propostos, justamente pelo caráter negociável da significação. A deformidade na decodificação se verifica quando os destinatários fazem uma interpretação da mensagem completamente diferente das intenções do emissor e do modo como ele previa que a decodificação fosse executada. Nestes casos, 
se percebem as diferenças nas competências interpretativas do destinador e do destinatário, e entre os diferentes níveis culturais e contextuais que criam a significação da mensagem.

Em relação aos modelos comunicacionais anteriores, o modelo semiótico-textual, conforme proposto por Umberto Eco e Paolo Fabbri, em torno de 1979, representa um novo delineamento teórico e uma nova reorganização metodológica da pesquisa em comunicação, pois já não situa a mensagem no centro do processo comunicativo, mas sim o texto, entendido como um grande tecido intertextual de significação, composto por uma série de fragmentos, códigos e linguagens, provenientes de outros textos, onde as várias linguagens se articulam, se interpenetram, colidem. Esta transformação do referencial teórico surge a partir da evolução interna da própria teoria semiótica e vem complementar o modelo semiótico-informativo, estabelecendo que os destinatários não recebem somente uma única mensagem, reconhecível e formulada com base em um determinado código, onde será decodificada a partir dos códigos dos destinatários, mas sim recebem conjuntos de práticas textuais. Além do mais, esta multiplicidade de mensagens que os destinatários emitem e recebem localiza-se não mais no âmbito interno de um "sistema fechado" laboratorial, como nas categorias idealizadas pelos modelos precedentes, mas no complexo espaço polissêmico de uma determinada cultura, heterogênea, multifacetada e imprevisível por sua própria natureza.

\section{O papel da codificação na relação texto e circunstância de comunicação}

Como se percebe, esta transformação no recebimento de conjuntos textuais por parte dos destinatários, ao invés de mensagens, e a necessidade de uma competência textual sustentada e enriquecida por um contexto cultural, representam um grande avanço em relação ao modelo semiótico-informativo. Neste modelo, a informação era vista apenas como um continuum de dados propagados através de um único código, não se levando em consideração o aspecto assimétrico presente entre emissor e receptor, objetificados enquanto pontos na cadeia comunicativa de transmissão da informação. A partir de tais reflexões, Umberto Eco (2001) preocupa-se com a diferença de códigos entre remetentes e 
destinatários, para os quais concorre uma determinada circunstância comunicacional que é própria e específica para cada enunciado.

Em outras palavras, no envio de um sinal qualquer como, por exemplo, "I vitelli dei romani sono belli” ${ }^{3}$ (ECO, 2001: 42), temos uma mensagem composta de sons vocais ou de signos gráficos, cujo canal pode ser constituído por ondas acústicas ou pelo papel em que está escrito. Nesta proposta, o receptor, entendido enquanto transmissor pelo modelo matemático-informativo, pode ser o ouvido, que converte vibrações acústicas em imagens sonoras, ou o olho, que converte traços de tinta em percepções visuais. O enfoque, dado agora ao ponto de chegada da mensagem, acarreta uma transformação de um modelo em relação ao outro, enfatizando o papel do receptor. No mais, o que Umberto Eco (2001) está interessado é na diferença entre a mensagem como forma significante e a mensagem como sistema de significados.

A mensagem como forma significante é a configuração gráfica ou acústica. 'I vitelli dei romani sono belli', que pode subsistir mesmo se não for recebida, ou se for recebida por um japonês que não conheça o código da língua italiana. Ao contrário, a mensagem como sistema de significados é a forma significante que o destinatário, baseado em códigos determinados, preenche o sentido. (ECO, 2001: 42).

Nestes termos, teríamos então uma forma significante que permanece imutada, e um ou múltiplos significados que se transformam conforme o código a ser utilizado pelos emissores/receptores. “Em latim é: ‘Vai, Vitélio, ao som de guerra do deus romano’ e em italiano, se quisermos realmente reportar a mensagem ao interpretante que lhe compete, significa que os nascidos de vacas criadas pelos nossos antigos progenitores (ou pelos atuais habitantes da capital italiana), são agradáveis de ver”. (ECO, 2001: 43). Certamente, quanto mais nos reportássemos à apropriação de um léxico conotativo particular, mais inusitadas e criativas interpretações seriam oriundas, uma vez que teríamos de levar em consideração a relação da língua italiana, e, portanto, de seus falantes, com a cultura que lhes dá sustentação.

\footnotetext{
${ }^{3}$ A frase "I vitelli dei romani sono belli" citada no exemplo acima, foi proposta para os alunos de algumas das escolas de ensino médio italianas como uma espécie de enigma, uma vez que pode ser lida (decodificada) tanto em latim quanto em italiano. Umberto Eco (2001) se vale desse exemplo para reiterar a diferenciação entre forma significante e significado.
} 
Em função da complexidade envolvida em um processo comunicacional, poderíamos supor uma situação paradoxal em que o remetente emitisse a referida mensagem reportando-se ao código da língua latina e que o destinatário a decodificasse reportando-se ao código da língua italiana, haja vista a influência daquela sobre essa. “Ora o código denotativo pode mudar de forma radical, dando origem a mensagens polissêmicas do tipo citado; ora a polissemia pode ser reduzida como quando digo 'aquele caríssimo cãozinho', onde não está claro se o cachorrinho é querido ou custa um preço demasiadamente alto”. (ECO, 2001: 43).

Outro caso ainda poderia ocorrer se levássemos em consideração o fato de um remetente emitir uma determinada mensagem se reportando a um certo código e que terminasse por ser decodificada pelo destinatário, remetendo-a à outro. Característica de uma codificação/decodificação entre limiares, esse “desencaixe” digamos assim, entre códigos constitui-se em uma condição normalmente encontrada na comunicação mais informal, do tipo gestual, em que um dado discurso pode ser "transformado" em um determinado gesto ou conjunto de gestos. Exemplo disso pode ser observado na conversação cotidiana ensejada por um “bom dia, tudo bem?”, recebendo como resposta de nosso possível interlocutor o gesto afirmativo "traduzido" pelo dedo polegar da mão direita apontando para cima, de resto um costume presente desde a época em que ocorriam os enfrentamentos entre romanos e cristão no antigo Coliseu, quando a vida desses últimos era poupada por àqueles, tendo como misericordiosa virtude a clemência para com o escravo. Ao refletir sobre a riqueza do contato entre os códigos de emissor e destinatário envolvidos em um processo comunicacional, Umberto Eco (2001) defende a idéia de que essa polissemia pode ser esclarecida e orientada por vários elementos:

um é o contexto interno do sintagma (isto é, o sintagma como contexto) que pode fornecer as chaves para a interpretação do resto; o outro é a circunstância de comunicação, que me permite compreender a que código o remetente está se referindo (assim a frase sobre os vitelos, do momento em que aparece nas gramáticas latinas, ou num contexto geral escrito inteiramente em latim, é mais facilmente decodificada em relação ao código da língua latina); finalmente, pode subsistir uma explícita indicação de código, contida na própria mensagem (por exemplo, "o significado no sentido que lhe confere Saussure ... "). (ECO, 2001: 43). 
Para o autor, a Semiologia de vertente saussureana dedica-se a reconhecer processos de codificação e, conseqüentemente, de produção de sentido, para os quais determinados significantes correspondem a determinados significados, e não a estabelecer se os significantes também se referem a uma realidade objetiva, uma vez que a Semiologia é a ciência da cultura, e não da natureza. A ressalva que o autor faz a esse respeito é a de que é mais interessante saber até que ponto o signo se refere a algo experimentável, e se isso realmente acontece, do que propriamente objetificá-lo. A discussão levantada por Eco nos faz lembrar que o âmbito da cultura é, sobretudo, o domínio da interpretação e da representação desses “objetos” que são expressos através de signos, cada vez mais (re) significados ao longo da História.

\section{Das (re) significações à necessidade de uma competência enciclopédica}

A revisão do papel da circunstância de comunicação traz implícita a necessidade de um outro olhar sobre a Semiologia, conforme nos coloca Eco (2001), justamente no que se refere ao compartilhamento de determinados códigos pelos leitores/sujeitos/receptores e sua apropriação em uma determinada situação comunicacional, ou a transformação de um código em outro, como nos informa, por exemplo, outra comunicação cotidiana, em que teríamos como forma de agradecimento (verbal), o aplauso ao final de um espetáculo. Nas seqüências significantes de um processo comunicacional, os fatores externos tais como os valores atribuídos por uma sociedade a determinados signos; a vivencia cultural dos receptores que fizeram uso desses signos; a própria estrutura política e ideológica presente nos signos, e que são do patamar da História, localizada em um dado tempo e espaço, interferem diretamente no processo de (re) significação. Bakhtin (1997), nos dirá, em outras palavras, que todo o signo é habitado, morada não só de uma sociedade, mas do próprio sujeito criador de signos e senhor da linguagem. Para Umberto Eco (2001),

é a própria circunstancia de comunicação (que a Semiologia não codifica nas suas várias possibilidades de realização, mas prevê como elemento fundamental no processo de recepção da mensagem), que se apresenta como uma espécie de referente da mensagem. No sentido, porém, de que a mensagem não indica o 
referente, mas se desenvolve no referente, na situação concreta que contribui para dar-lhe sentido. (ECO, 2001: 44).

Ao escutarmos, principalmente entre os adolescentes, que uma determinada festa estava "bala”, mensagem referendada por um aporte lingüístico, e legitimada por uma competência de dicionário, certamente aqueles jovens não estão se referindo às guloseimas ofertadas às crianças, nem tampouco aos projéteis utilizados como armamento, mas sim, a determinados aspectos circunstanciais proporcionados pela própria codificação da mensagem, tais como uma música dançante, belos garotos e garotas, bebidas alcoólicas geladas, etc, que se “intrometem” no interior lingüístico, dando-lhe outro significado e acrescentando-lhe elementos que, inicialmente, não lhe diziam respeito. No sentido concedido à mensagem “aquele homem é um gato!” estamos acrescentando muito mais aspectos que nos chegam através de uma tradição cultural, “externa”, digamos assim, ao conteúdo da mensagem, do que propriamente àqueles que o código lingüístico nos oferece.

Não se trata de descartar os aspectos lingüísticos presentes na mensagem, fundamentais para os processos comunicacionais e de produção de sentido, mas levar em consideração que as qualidades da beleza, meiguice e languidez do “objeto” gato tratado enquanto animal felino, mamífero, etc, são associadas a um certo ideal de beleza que atribuímos a um homem cujos aspectos essenciais lhes são constituintes. Tal associação, que nos é passada através de uma circunstância de comunicação, extrapola uma codificação primeira para se consagrar através de um procedimento interpretativo, que pode remeter ao mito grego da beleza. Segundo Platão, só à beleza, entre todas as substâncias perfeitas, “coube o privilegio de ser a mais evidente e a mais amável.” Por isso, na beleza e no amor que ela suscita, o homem encontra o ponto de partida para a recordação ou a contemplação das substâncias ideais (Fedro, 250 - 251, apud Abbagnano, 1962, op. cit.: 101).

Para além da simplicidade da mensagem que nos informa que "aquele homem é um gato!”, temos presente todo um patrimônio cultural que nos dirá que existem cinco conceitos fundamentais defendidos pela Estética: o Belo como manifestação do Bem; o Belo como manifestação da Verdade; o Belo como simetria; o Belo como perfeição sensível e o Belo como perfeição expressiva, e que nos reportará à teoria platônica do Belo 
enquanto uma Doutrina do Bem. Por ser considerado bonito a partir de um determinado patrão estético, esse homem empresta suas qualidades divinas a um animal meigo, grácil e amável. Se formos analisar o pensamento filosófico da época, à luz dos paradigmas do nosso tempo, pode-se perceber que os gregos antigos, contemporâneos de Platão e Aristóteles, já acreditavam em uma possibilidade de construção da beleza, conceito teórico que com a evolução dos séculos e das técnicas de produção e reprodução, vem sendo absorvido e remodelado conforme as circunstâncias históricas e comunicacionais de cada momento e, principalmente, de (re) significação, negociação e remanejamento de certos elementos da cultura, sob a base de um ou mais códigos. Expresso de outro modo,

Se digo a palavra "porco", não importa que ao termo corresponda ou não determinado animal, importa, isto sim, o significado em que a sociedade em que vivo atribui a esse termo, e as conotações com que o envolve (pode ser um animal impuro, pode ser usado em sentido translato como insulto); a existência real do porco-referente importa com respeito à natureza semiológica do signo, tanto quanto o fato de existirem ou não bruxas quando insulto uma mulher chamando-a de bruxa. Mas se o enunciado "aquele é um belo porco" se pronuncia na "criação suína", ou então na circunstância "discurso sobre um amigo", vemos que o alcance do termo se modifica consideravelmente de um para o outro caso. A presença do referente induz-me a identificar o léxico conotativo mais apto; a realidade orienta-me para os códigos adequados.(ECO, 2001: 44).

Deste modo, o “porco", citado no exemplo acima, pode ser emitido/recebido por nossos possíveis interlocutores como se referindo também à fertilidade; à abundância, seja de carne ou gordura; ou ainda à uma possível sordidez de comportamento, ou fraqueza de caráter, por exemplo, sendo associado a algum aspecto detestável a que os emissores/receptores estejam se referindo, características ausentes no “animal porco”, raça doméstica de Sus scrofa, artiodátilo não ruminante da família dos suínos, animal que o homem cria e engorda para dele retirar inúmeros benefícios. Por tais razoes, Umberto Eco (2001) faz a ressalva de que

nem sempre a circunstância se identifica com o suposto referente do signo, porque pode constituir uma situação global de onde o referente está ausente e que, no entanto, me orienta para o significado coligado. A circunstância é a presença de uma realidade à qual, por experiência, fui habituado a aliar o emprego de certos significados em lugar de outros. (ECO, 2001: 44). 
Como se percebe, estamos diante de uma situação em que, além das hierarquias de códigos envolvidas no processo e das competências lexicais estabelecidas entre emissores e receptores, é a circunstância da comunicação que termina por indicar o sentido de uma dada mensagem. Este “contexto externo” ao código lingüístico parte de um dicionário mínimo, fundamental para a compreensão de uma dada mensagem em que se suponha um possível entendimento entre sujeitos, e reclama uma competência enciclopédica, como Umberto Eco (1986 - 1991) chama esse conhecimento plural, constituído pela convergência de inúmeros fatores cognoscentes associados entre si e necessários para a decodificação dos diferentes sistemas intertextuais que envolvem o processo comunicativo. Essa qualidade interpretativa está presente como articuladora e mediadora entre os dois pólos da relação comunicacional, armazenada culturalmente sob a forma, justamente, de um saber enciclopédico. Longe de produzir uma transmissão de informação de sentido unívoco, a heterogeneidade de fatores envolvidos no entendimento entre emissores e receptores traz à tona complexos jogos interpretativos, que ora se antagonizam, ora se complementam, ora se harmonizam na produção de um determinado sentido.

Em outras palavras, ao estar inserida em um certo contexto social, histórico, cultural, político e ideológico, uma determinada mensagem sofrerá as influências do ethos comunicacional em que foi emitida/recebida, bem como as interações/interpretações dos sujeitos que lhe atualizarão seus possíveis significados. Tal ponto de vista enfatiza a necessidade de observação da instância relacional que se dá entre a história, o tempo particular e o lugar de geração do enunciado, com a seqüência de envolvimentos intersubjetivos que de algum modo se ligam e tocam àquela mensagem. Deste modo, para Eco (2001),

a circunstância muda o sentido da mensagem (uma bandeira vermelha na praia não tem o mesmo significado de uma bandeira vermelha em uma manifestação de rua; as nervuras internas da Igreja da Rodovia ${ }^{4}$ conotam elevação mística, ao passo que num pavilhão industrial exprimem valores tecnológicos e

\footnotetext{
${ }^{4}$ A Igreja da Rodovia (Chiesa dell’Autostrada), como ficou conhecida, está localizada na Rodovia do Sol, entre Bolonha e Florença, e é obra recente, segundo Umberto Eco, datando de 1964, e uma das mais representativas da moderna arquitetura italiana.
} 
funcionais); a circunstância muda a função da mensagem: um sinal de contramão, na rodovia, tem um impacto emocional e um valor imperativo bem maior do que um sinal de contramão dentro de um pátio de estacionamento; a circunstância muda a cota informativa da mensagem (ao passar do rótulo da garrafa para o distintivo do homem corajoso, o signo da caveira sofre uma mutação parcial de sentido; mas o mesmo signo colocado numa cabine elétrica, apresenta-se mais redundante, mais previsível, do que quando damos com ele numa garrafa de cozinha). (ECO, 2001: $44-45)$.

Situação muitas vezes imprevisível, a circunstância da comunicação, específica e própria para cada instante comunicacional, introduz-se no universo semiológico, e, portanto, no universo das convenções culturais, como um fator que não pode ser negligenciado, uma vez que se apresenta como a expressão de uma situação peculiar que, de alguma forma, associa-se ao processo de produção de sentido. Se o sistema da língua, conforme referido por Saussure, é apropriado pelo homem para seu uso na linguagem, isso se dá contexto concreto da vida cotidiana, para o qual concorrem a atualização dos diferentes sistemas de códigos e a relação desse engenhosos mecanismos com as relações de produção de sentido que se interligam à História, à sociedade e à natureza.

Nestes termos, devemos levar em consideração, em um processo comunicacional, as articulações estabelecidas entre um código denotativo de base e um código conotativo, originado, justamente, das transformações que o primeiro sofre em relação à circunstância da comunicação dada pelo contexto social, cultural, político. A denotação se refere aquelas características do código estabelecido entre os interlocutores de um processo comunicacional tendo em vista, a priori, as diferentes estruturas lingüísticas, mas supondo como quadro de referência uma dada língua, entendida enquanto sistema organizado de regras. Pelos aspectos denotativos, estaríamos, destarte, vinculados a uma certa imposição do código verbal, constituído por palavras que organizariam nosso discurso, entendido aqui como forma de comunicação. “A relação de denotação é uma relação direta e unívoca, rigidamente fixada pelo código”. (ECO, 2001: 27).

Por outro lado, o código conotativo se relaciona ao modo pelo qual uma determinada sociedade lê uma mensagem, atribuindo-lhe um significado estético, ideológico, social, cultural, etc. A conotação transfere para o código elementos que pertencem à cultura. A cultura é que fornece aos códigos os estereótipos, as circunstâncias e 
as matrizes da codificação. As ações, as vivências e as interpretações dos sujeitos acerca das mensagens interferem diretamente na transmutação desses elementos em outros, e na criação e (re) significação dos códigos. É justamente nesse nível que se inserem, para Eco (2001), as oscilações de sentido proporcionadas pelo forte apelo conotativo presente em algumas mensagens, não só as de cunho poético, que se valem de metáforas, ironias, ou imagens capazes de gerar múltiplos significados, mas também as comunicações cotidianas, como no exemplo “os operários devem permanecer em seu posto”, capaz de produzir cumplicidades e incompreensões entre os falantes.

No plano denotativo, seu sentido afigura-se unívoco para quem compreenda a língua portuguesa, mas o código não me esclarece qual seja o posto dos operários. Devo recorrer, para decodificar o enunciado, a léxicos conotativos que abarquem o segundo sentido de expressões como "permanecer em seu posto" ou "o posto dos operários". E percebo que posso utilizar dois diferentes léxicos conotativos que se referem a duas situações culturais e a duas posições ideológicas distintas. Posso ler a frase em chave conservadora, conferindo-lhe estas conotações: "Os operários devem permanecer no posto que a sorte lhes destinou, sem tentarem forçar o equilíbrio social”; ou então posso lê-la em chave revolucionaria, no sentido de: “Os operários devem permanecer no posto que a dialética da História lhes atribui, isto é, no vértice do poder, realizando a ditadura do proletariado. (ECO, 2001: 45 - 46).

Como se percebe, no momento em que um destinatário está diante de uma dada mensagem, seja ela ambígua ou não, ele recorre a certos códigos e léxicos de interpretação, para os quais concorrem determinadas circunstâncias comunicacionais, que serão mais ou menos influenciadas pelo contexto gerativo dessa mensagem e para a qual existirá, de alguma forma, uma determinada indicação de código a ser seguida, a princípio explicitada pela própria mensagem. Umberto Eco (2000) estabelece, então, que “um código é um sistema de significação que une entidades presentes e entidades ausentes. Sempre que, com base em regras subjacentes, algo materialmente presente à percepção do destinatário está para qualquer outra coisa, verifica-se a significação”.(ECO, 2000: 06). Temos então, a partir deste destinatário, um processo de significação que solicita uma resposta interpretativa por parte de um destinatário. Entretanto, 
fique bem claro, porém, que o ato perceptivo do destinatário e seu comportamento interpretativo não são condições necessárias da relação de significação: basta que o código estabeleça uma correspondência entre o que está para e seu correlato, correspondência válida para todo o destinatário possível, ainda que não exista ou não possa existir nunca um destinatário. (ECO, 2000: 06).

Assim sendo, o processo de significação se verifica com o estabelecimento de um código, sistema convencionado social e culturalmente pelos sujeitos empíricos de uma dada cultura. Tal situação termina por remeter para uma competência enciclopédica relacionada ao patrimônio cultural, social, político, ideológico posto em contato entre emissores e receptores de um dado processo comunicacional. Através das mediações culturais, ocorre a circulação das práticas textuais, que são fatores decisivos para a compreensão do processo comunicativo, uma vez que a ênfase deixa de estar colocada unicamente no pólo emissor, passando a adquirir relevância justamente a dinâmica existente entre destinador e destinatário, com o devido reconhecimento de suas diferenças e, principalmente, do papel desenvolvido por ambos os pólos na atividade de construção e funcionamento da significação textual.

\section{Referências Bibliográficas}

BAKHTIN, Mikhail (VOLOSHINOV). Marxismo e filosofia da linguagem. São Paulo: Hucitec, 1997.

ECO, Umberto. A estrutura ausente. São Paulo: Perspectiva, 2001.

A procura da língua perfeita. Lisboa: Presença, 1996.

_. Interpretação e superinterpretação. São Paulo: Martins Fontes, 2001.

_. Kant e o ornitorrinco. Rio de Janeiro: Record, 1998.

_. Lector in fabula. São Paulo: Perspectiva, 1986. 
Revista da Associação Nacional dos

Programas de Pós-Graduação em Comunicação

\section{compós}

__. Obra aberta. São Paulo: Perspectiva, 1968.

O conceito de texto. São Paulo: EDUSP, 1984.

. Os limites da interpretação. São Paulo: Perspectiva, 2000.

_. Seis passeios pelos bosques da ficção. São Paulo: Cia. das Letras, 2001.

—_. Semiótica e filosofia da linguagem. São Paulo: Ática, 1991.

__ Sobre os espelhos e outros ensaios. Nova Fronteira: Rio de Janeiro, 1989.

. Tratado geral de semiótica. São Paulo: Perspectiva, 2000.

GRANDI, Roberto. Texto y contexto en los medios de comunicación: análisis de la información, publicidad, entretenimiento y su consumo. Barcelona: Bosch, 1995.

NÖTH, Winfried. Panorama da semiótica: de Platão a Pierce. São Paulo: Annablume, 1998.

. A semiótica no século XX. São Paulo: Annablume, 1999.

PESSOA DE BARROS, Diana Luz. Teoria do discurso. São Paulo: Atual, 1988.

. Teoria semiótica do texto. São Paulo: Ática, 2001. 